International Journal of Engineering \& Technology, $7(4.36)(2018) 599-603$
International Journal of Engineering \& Technology
WPC
Website: www.sciencepubco.com/index.php/IJET
Research paper

\title{
Analyzing the Business Performance of An Erp Systems in Automotive Ancillary Industries-Balanced Scorecard Perspective
}

\author{
Srinivasan Lakshmanan ${ }^{1 *}$, S. Edmund Christopher ${ }^{2}$, D. Kinslin ${ }^{3}$ \\ ${ }^{1}$ Research Scholar, Department of Management Studies, Noorul Islam Centre for Higher Education, Kumaracoil, Kanyakumari District, \\ Tamil Nadu, India. \\ ${ }^{2}$ Dean of Academic Affairs, ECMIT, Al Nhada, Dubai. \\ ${ }^{3}$ Assistant Professor and Chair of General Education, Emirates College of Management and Information Technology, Al Nahda-2, \\ Dubai.E-mail:kinslin@ecmit.ac.ae \\ *Corresponding author E-mail:meet.lsrinivasan@gmail.com
}

\begin{abstract}
This study aims to analyze the business performance of Enterprise Resource Planning (ERP) system in Automotive Ancillary Industries using four interrelated dimensions of performance measurement framework Balanced Scorecard (BSC); Innovation and Learning, Internal, Customer and Financial perspective. This analysis was carried out based on survey questionnaires with 281 stakeholders who are familiar with ERP system and results were presents as evidence. The analysis result shows that uses of ERP system resulted in a positive in financial performance of the organization, deliver best services to their customer, increases the overall internal performance of the firm increases and enhances firm loyalty and simplify the complex work. Friedman's ranking analysis and correlation analysis were applied, and detailed analysis was submitted in this study. The results from the survey indicate that integrated software system such as ERP need to be implemented in Automotive Ancillary Industries to improve the business performance in various dimension i.e. Innovation and Learning, Internal, Customer and Financial perspective.
\end{abstract}

Keywords: Automotive ancillary industry, balanced scorecard; enterprise resource planning; business performance.

\section{Introduction}

The present worldwide business brought in new competitions, new environment, new challengesand new opportunities. This has resulted in decreasing product life cycles and reducing profit margins. To anticipate and respond quickly to the changing business conditions, the firm needs a solid information system that supports all aspects of business with power and flexibility. Global ERP market registered huge growth in the past decades. In automotive industry in the world is under unbelievable pressure for the past few years due to volatile demand and excess contribution from developed countries, As a result the Automobile Industries across the globe looking for marketplace with increasing requirement and locations for cheaper supply. Developing countries like the Czech Republic and Mexico are economical sourcing for the top automotive in the world. In recent year's Asian countries China and India developed as the lowpriced auto components and low-cost sourcing for automobiles. Automobile industries need ERP system as a solution for the best practice and streamlined business process. By implementing ERP systems, it attains some benefits include coordination of enterprise-wide operations between or within the firm, inventory control functionality for storage product, rapid real-time data sharing and accessing the information at any time anywhere, customizable interfaces, and scalable for growing business [1]. Therefore; automobile industry has been selected for this study to analyze the performance measure. The result of the study provides a clear-cut idea about the different business process.

This study was carried out to analyze the business performance of ERP system by means off our interrelated dimensions of performance measurement framework Balanced Scorecard (BSC); Innovation and Learning, Internal, Customer and Financial perspective. of the balanced scorecard (BSC) framework namely Financial, Customer, Innovation and Learning and Internal There is a growing body of scholars recommending that BSC is the best method to analyze the business performance of the ERP System [2].The uses of BSC have been analyzed with regards to IT and data frameworks and it can be applied to Information Technology functions where they categorized in to balance scorecard (BSC) measurements of finance, customer, learning and growth as userorientation, internal business processes, operational excellence and future orientation and corporate contribution, respectively. [3]

1) What are the impacts of ERP towards the business performance in financial perspectives?

2) What are the impacts of ERP towards the business performance in customer perspectives?

3) What are the impacts of ERP towards the business performance in internal perspectives?

4) What are the impacts of ERP towards the business performance in Innovation and Learning perspectives? 


\section{Literature review}

Enterprise Resource Planning (ERP) System is an integrated software system. It integrates various departments within and across the firm. ERP System accesses the central database to retrieve entire departments data of firm. (1). This is the major benefits of ERP and many firms implement this system to achieve this benefit. The ERP Selection, Implementation requires a lot of money, time and many efforts from the functional team to map the business process. This paper presents the journey after ERP implementation in the firm and explain how to analyze and examine the Performance of an ERP system.

Automotive Industries is a vital industry in the manufacturing sector that comprise continuous movement of material from the raw material, intermediate material or finished product that are procured, transformed, stored and sold. Manufacturing costs are rising. Demands are dynamically changing. Business globalization is changing the competitor, manufacturers, distributors, dealers and suppliers landscape. They are responding to these challenges by looking the demand and supply of the current trend. ERP is extensively helpful in active supply chains in automotive logistics to manage, monitor and reduce the cost. It clarifies the business processes and improves delivery accuracy to the customer (5). The Man, Machine, money, method are integratedinto ERP. ERP helps the firm to build a supply chain in such a way that easier to manage, anticipate and respond quickly to dynamic changes in the market conditions (16). It also makes the firm more competitive, like service, productivity, and innovation.

ERP system provides some merits for firms to enhance and improve the firm performance. ERP system implementation improves the relations between various business functions in the firm and the information is available and accessible in the system. ERP systems have more merits in the integration of operation and business processes between various functions in the firm, but it will not reduce the IT costs [6], ERP systems have numerous advantages, which might be attained by the firm. These benefits differ from five major benefits which comprise managerial benefits, Tactical benefits, strategic benefits, operational benefits, IT infrastructure design and firm benefits. A BSC is the appropriate evaluation processes which assures more accurate results and smooth and faster the progress of assessments for decision-makers. Decisions based on accurate performance result may lead to more effective and efficient way of attaining the management strategic objectives [7]. Evaluation of ERP success is a difficult approach; if the result of an ERP System evaluation is utilized as a source for measures for an improvement of the business performance then the results of improvements can be measured through a new assessment of the ERP system performance using a comparison of the outcome of each evaluation. So, the upcoming research will be encouraging to investigate and study the result of an ERP system in a poor dimension (in sequence quality flexibility of accessing system, reduces quality and maintenance costs, improve resource utilization) where improvements should be made [8]

An ERP implementation success has the advantages of reducing the cost, reducing the time of the process and quality of the product [9]. It gives the benefits to its customers on purchase required goods or products at cheaper price and shares the information of production status in real time [10]. The Successful ERP system brings business performance improvement and benefits to the firm. To get the good ERP Implantation, system must be managed by the wide-ranging firmal change of presentsoftware installation [11]. Many business firms implemented ERP software systems to attain the required benefits and process they needed [12]. After successfully ERP software implementation, companies can make standards in finance related transactions and operating measures for tracking real-time inventory and warehouse systems[13]. The operational advantages of ERP software system incorporate effectiveness measures of turn-cycles reduction in the elaboration of reports, quickness in information sharing, and changes in information quality because of lessened redundancies. ERP is attached to decrease the cost which prompts enhancing exhibitions in the production network effectiveness, quicker monetary detailing, more precious information and a higher limit with regards to delivering highly qualified and a procedure focused mindset [17]. ERP is noted for more efficiencies to reduce labor costs, inventory cost and faster financial relating monthly and yearly closings. It improves managers decision making and judgment who can retrieve real time data and reports and Top Management expectations on effective utilization of resource using ERP software system [15] The management expectation with ERP Software system is to share real time information with customer and supplier to plan their business effective way by using Customer Relationship Management and Supplier Relationship Management modules Qu et al. [14] gives ERP system should have capable to plan for long term planning, forecast planning for organizations internal and strategic policy and procedure implementation.

\section{Research methodology}

The Balanced Scorecard (BSC) performance measurement framework was designed for business performance measurement of automobile ancillary as illustrated below in various perspectives;

- The financial perspective

It looks at what should be done for the organization to succeed financially.

- The customer perspective

It shows an increasing customer satisfaction with product and process in their business which will increase Customer profitability, Increasing customer retention and loyalty and corporate image

- The Internal Perspective

It is concerned with how the user benefits from using the system in terms of ease in workload and simplification of tasks

- The Innovation and Learning \& Growth Perspective It looks at what an organization should do to achieve its vision.

Table 1: ERP Strategic Measurements from BSC

\begin{tabular}{|c|c|c|}
\hline $\begin{array}{l}\text { Strategic } \\
\text { Perspective }\end{array}$ & $\begin{array}{l}\text { ERP Business } \\
\text { Performance }\end{array}$ & Strategic Measures \\
\hline \multirow[t]{4}{*}{$\begin{array}{l}\text { Financial } \\
\text { Perspective }\end{array}$} & \multirow{4}{*}{$\begin{array}{l}\text { Operating cost } \\
\text { Reduction } \\
\text { Revenue Increase }\end{array}$} & $\begin{array}{l}\text { Net Operating profit } \\
\text { improvement }\end{array}$ \\
\hline & & $\begin{array}{l}\text { Return on Investment } \\
\text { improvement }\end{array}$ \\
\hline & & Sales growth improvement \\
\hline & & $\begin{array}{l}\text { Inventory turnover rates } \\
\text { reduction }\end{array}$ \\
\hline \multirow[t]{4}{*}{$\begin{array}{l}\text { Customer } \\
\text { Perspective }\end{array}$} & \multirow{4}{*}{$\begin{array}{l}\text { Customer } \\
\text { satisfaction } \\
\text { Corporate Image } \\
\text { improvement }\end{array}$} & $\begin{array}{l}\text { Product delivery time } \\
\text { reduction }\end{array}$ \\
\hline & & $\begin{array}{l}\text { Product delivery rate } \\
\text { improvement }\end{array}$ \\
\hline & & $\begin{array}{l}\text { Corporate Image } \\
\text { improvement }\end{array}$ \\
\hline & & $\begin{array}{l}\text { Customer reaction \& } \\
\text { satisfaction improvement }\end{array}$ \\
\hline \multirow[t]{4}{*}{$\begin{array}{l}\text { Internal } \\
\text { Perspective }\end{array}$} & \multirow{4}{*}{$\begin{array}{l}\text { Time Reduction } \\
\text { Optimum Utilization } \\
\text { of firm resources }\end{array}$} & $\begin{array}{l}\text { Invoice processing time } \\
\text { reduction }\end{array}$ \\
\hline & & $\begin{array}{l}\text { Capacity utilization } \& \\
\text { Overall performance } \\
\text { Improvement }\end{array}$ \\
\hline & & $\begin{array}{l}\text { Manufacturing cycle time } \\
\text { reduction }\end{array}$ \\
\hline & & $\begin{array}{l}\text { Order processing time } \\
\text { reduction }\end{array}$ \\
\hline Innovation & $\begin{array}{l}\text { Enhancing employee } \\
\text { productivity }\end{array}$ & $\begin{array}{l}\text { Employee's Productivity } \\
\text { Enhancement }\end{array}$ \\
\hline
\end{tabular}




\begin{tabular}{|l|l|l|l|}
\hline $\begin{array}{l}\text { Learning } \\
\text { Perspective }\end{array}$ & $\begin{array}{l}\text { Standardize the } \\
\text { business process }\end{array}$ & $\begin{array}{l}\text { Employee Loyalty } \\
\text { enhancement }\end{array}$ & Human error reduction \\
\cline { 3 - 4 } & $\begin{array}{l}\text { Complexity routine work } \\
\text { Simplification }\end{array}$ \\
\hline
\end{tabular}

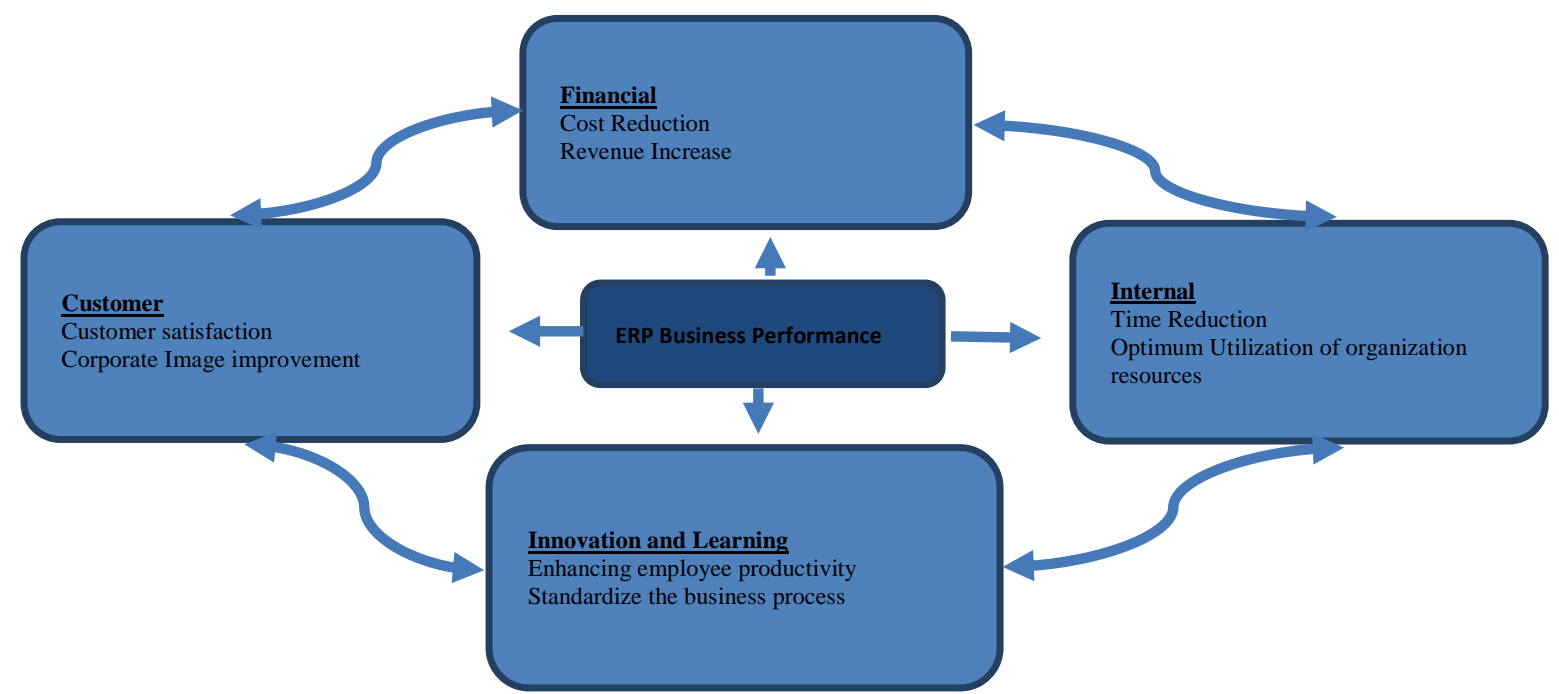

Fig. 1: ERP implementation business performance Balanced Scorecard

\subsection{Survey design}

The survey construct was designed for this study and data were collected. This study used primary as well as secondary data. Secondary data were collected from the thesis, websites, various journals, and books. The primary data for the KPIs were collected from the Business Process owners[BPOs], Top level Management and middle-level managers and various business users involved in the ERP Implementation \& Usage. A five-point scale (1 denotes strongly disagree and 5 denotes strongly agree) was applied sensitivity of this measure.

The various Key Performance Indicator were identified by the researcher in her pilot study. They were analyzed using four interrelated dimensions of performance measurement framework Balanced Scorecard (BSC); Innovation and Learning, Internal, Customer and Financial perspective. The ranking given by the ERP Business users per their opinions were analyzed with the help of Friedman ranking techniques, and the mean scores are presented in Table.

\subsection{Data collection and sampling method}

Questionnaires were sent to the respondents through Hard copy and mail. Data were collected from 281 respondents who are all having very good knowledge of business process and ERP usage in Automobile ancillary industries who are all manufacturing. The data is collected from Top 20 component manufacturing firm in Tamilnadu with different manufacturing parts. Like Drive and Transmission parts, suspension and breaking Systems, Engine and Engines parts, Electrical Parts and Glass Parts. Multistage Random Sampling method used to collect the data from 1100 ERP users.

\section{Data analysis hypothesis testing}

Collected data were analyzed by using the software package SPSS and Analysis of Moment Structure (AMOS) Version 20.0. Reliability Statistic Cronbach's alpha was calculated, examined for validating the internal consistency and reliability statistics scales of the construct for 30 samples. Reliability Statistic Cronbach's Alpha measured value has the value greater than 0.6 is ensure the the internal consistency of the reliability. Statistical techniques like descriptive analysis, Friedman Test, and Correlation Test were applied for data analysis and evaluating the different Performance measures of the ERP Implementation in Automobile Ancillary Industries in India,

Table 2 Shows Reliability statistic Cronbach's Alpha for internal consistency check for the Strategic measures

Table 2: Reliability Statistic Cronbach's Alpha

\begin{tabular}{|c|c|c|c|}
\hline Strategic Perspective & $\begin{array}{l}\text { Strategic } \\
\text { Measure }\end{array}$ & $\begin{array}{l}\text { Sample } \\
\text { Size }(\mathrm{N})\end{array}$ & $\begin{array}{l}\text { Cronbach's } \\
\text { Alpha }\end{array}$ \\
\hline \multirow[t]{4}{*}{ Financial Perspective } & $\mathrm{F} 1$ & 30 & \multirow[t]{4}{*}{0.8} \\
\hline & $\mathrm{F} 2$ & 30 & \\
\hline & F3 & 30 & \\
\hline & $\mathrm{F} 4$ & 30 & \\
\hline \multirow[t]{4}{*}{ Customer Perspective } & CU1 & 30 & \multirow[t]{4}{*}{0.643} \\
\hline & CU2 & 30 & \\
\hline & CU3 & 30 & \\
\hline & CU4 & 30 & \\
\hline \multirow[t]{4}{*}{ Internal Perspective } & I1 & 30 & \multirow[t]{4}{*}{0.64} \\
\hline & $\mathrm{I} 2$ & 30 & \\
\hline & $\mathrm{I} 3$ & 30 & \\
\hline & $\mathrm{I} 4$ & 30 & \\
\hline \multirow{4}{*}{$\begin{array}{l}\text { Innovation and } \\
\text { Learning Perspective }\end{array}$} & IN1 & 30 & \multirow[t]{4}{*}{0.929} \\
\hline & IN2 & 30 & \\
\hline & IN3 & 30 & \\
\hline & IN4 & 30 & \\
\hline
\end{tabular}

\subsection{Hypothesis}

Null Hypothesis: There is no significant difference among different performance measures mean ranks towards ERP Implementation in Automobile Ancillary Industries

Table 3 shows the Significant Difference in Friedman Test among different performance measures towards the ERP Implementation.

Table 3: The Significant Difference in Friedman Test

\begin{tabular}{|l|l|l|l|l|}
\hline Strategic Perspective & $\begin{array}{l}\text { Mean } \\
\text { Rank }\end{array}$ & Rank & $\begin{array}{l}\text { Chi-square } \\
\text { value }\end{array}$ & P value \\
\cline { 1 - 3 } Financial Perspective & 2.24 & III & \multirow{2}{*}{128.060} & $0.000^{* *}$ \\
\cline { 1 - 3 } Customer Perspective & 2.96 & I & & \\
\cline { 1 - 3 } Internal Perspective & 2.02 & IV & & \\
\cline { 1 - 3 } $\begin{array}{l}\text { Innovation and Learning } \\
\text { Perspective }\end{array}$ & 2.79 & II & & \\
\hline
\end{tabular}

** Denotes significant at $1 \%$ level

Since the $\mathrm{P}$ value is lesser than 0.01. in the above table, null hypothesis is rejected at the $1 \%$ level of significance. Thus, it is 
confirmed that there is a significant difference among different performance measures mean ranks towards ERP Implementation. From the mean rank, Customer Perspective (2.96) ranked first followed by Innovation and Learning Perspective (2.79). Financial Perspective occupies the third rank with the mean rank of 2.24 Internal Perspective is found to be the least Performance measures of ERP Implementation in Automobile Ancillary Industries. It has the lowest mean rank of 2.02

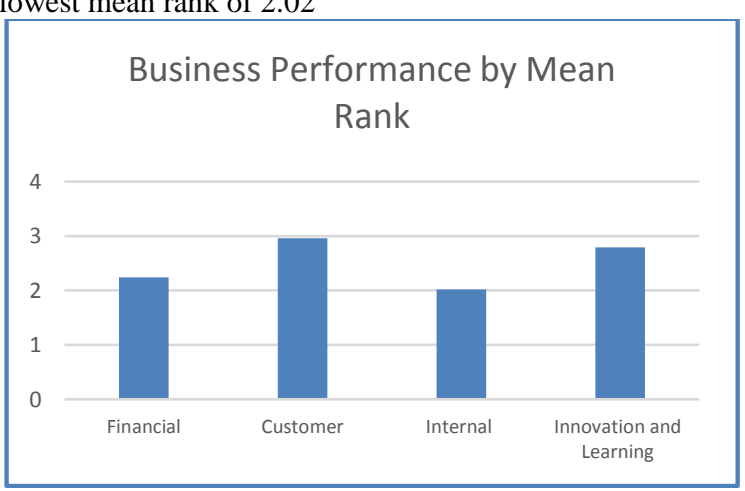

Fig. 2: Business performance by mean value

\subsection{Correlation analysis}

On performance measures in ERP Implementation in Automobile Ancillary Industries. Table 4 Showing Pearson Correlation Coefficient between performance measures in ERP Implementation in Automobile Ancillary Industries

Table 4

\begin{tabular}{|l|l|l|l|l|}
\hline $\begin{array}{l}\text { Strategic } \\
\text { Perspective }\end{array}$ & $\begin{array}{l}\text { Financial } \\
\text { Perspective }\end{array}$ & $\begin{array}{l}\text { Customer } \\
\text { Perspective }\end{array}$ & $\begin{array}{l}\text { Internal } \\
\text { Perspective }\end{array}$ & $\begin{array}{l}\text { Innovation } \\
\text { and } \\
\text { Learning } \\
\text { Perspective }\end{array}$ \\
\hline $\begin{array}{l}\text { Financial } \\
\text { Perspective }\end{array}$ & 1.000 & $0.386^{* *}$ & $0.570^{* *}$ & $0.350^{* *}$ \\
\hline $\begin{array}{l}\text { Customer } \\
\text { Perspective }\end{array}$ & - & 1.000 & $0.661^{* *}$ & $0.615^{* *}$ \\
\hline $\begin{array}{l}\text { Internal } \\
\text { Perspective }\end{array}$ & - & - & 1.000 & $0.524^{* *}$ \\
\hline $\begin{array}{l}\text { Innovation } \\
\text { and } \\
\begin{array}{l}\text { Learning } \\
\text { Perspective }\end{array}\end{array}$ & - & - & - & 1.000 \\
\hline
\end{tabular}

** Correlation is significant at $1 \%$ level

The correlation coefficient between performance Measure Financial Perspective and Customer Perspective is 0.386 , which shows 38.6 percentage positive relationships at $1 \%$ significant level. The correlation coefficient between Performance Measures Financial Perspective and Internal Perspective is 0.570, which shows 57.0 percentage positive relationships at $1 \%$ significant level. The correlation coefficient between Performance Measures Innovation and Learning Perspective and Financial Perspective is 0.350 , which shows 35.0 percentage positive relationships at $1 \%$ significant level. The correlation coefficient between Performance Measures Customer Perspective and Internal Perspective is 0.661, which shows 66.1 percentage positive relationships at $1 \%$ significant level.The correlation coefficient between Performance Measures Customer Perspective and Innovation and Learning Perspective is 0.615 , which shows 61.5 percentage positive relationships at $1 \%$ significant level. The correlation coefficient between Performance Measures Innovation and Learning and Internal Perspective Perspective is 0.524, which shows 52.4 percentage positive relationships at $1 \%$ significant level. From the above regression analysis result reveals that there are more positive relationships between different Strategic Perspective in different measure in business performance.

\section{Conclusion}

This study results contributes to knowledge management on ERP System in a better way of approach and contribution in the literature regarding business performance measures of Enterprise Resource Planning (ERP) system post-implementation phase as a measurement standard in Automotive Ancillary Industries using four interrelated dimensions of performance measurement framework Balanced Scorecard (BSC); Innovation and Learning, Internal, Customer and Financial perspective. From the Friedman's ranking analysis provides Performance measures on Customer Perspective is achieved followed by Innovation and Learning Perspective, Financial Perspective and Internal Perspective. The regression analysis reveals that there are more positive relationships between different Strategic Perspective.

All Management executives and are suspicious about achieving strategic objectives by using modern ERP System functionality. Evaluation and examine using systematic approach using BSC models improves business performance which assures more accurate information for smooth and faster assessments for decision-makers. Decisions based on accurate performance result may lead to more effective and efficient way of attaining the management strategic objectives. This study will encourage the ERP implementation in competitive, volatile, dynamic and knowledge-based economy in Automobile Ancillary Industry.

\section{References}

[1] Fernandez D, Zainol Z \& Ahmad H, "The impacts of erp systems on public sector organizations", the 8th International Conference on Advances in Information Technology, (2017).

[2] Van Grembergen W, Saull R \& De Haes S, "Linking the it balanced scorecard to the business objectives at a major canadian financial group", Journal of Information Technology Case and Application Research, Vol.5, No.1, (2003), pp.23-50.

[3] Kumar V, Maheshwari B \& Kumar U, "Erp systems implementation: Best practices in canadian government organizations", Government Information Quarterly, Vol.19, No.2, (2002), pp.147-172.

[4] Leon A, Enterprise resource planning, McGraw-Hill Education, (2014)

[5] Staehr L, Shanks G \& Seddon PB, “An explanatory framework for achieving business benefits from erp systems", Journal of the Association for Information Systems, Vol.13, No.6, (2012).

[6] Shang S \& Seddon PB, "A comprehensive framework for classifying the benefits of erp systems", AMCIS proceedings, (2000)

[7] Shen YC, Chen PS \& Wang CH, "A study of enterprise resource planning (erp) system performance measurement using the quantitative balanced scorecard approach", Computers in Industry, Vol.75, (2016), pp.127-139.

[8] Kronbichler SA, Ostermann H \& Staudinger R, "A comparison of erp-success measurement approaches", Journal of Information Systems and Technology Management, Vol.7, No.2, (2010), pp. 281-310.

[9] Lucas Jr HC, Walton EJ \& Ginzberg MJ, "Implementing packaged software", MIS quarterly, (1988), pp.537-549.

[10] Ifinedo P, "Interactions between organizational size, culture, and structure and some it factors in the context of erp success assessment: an exploratory investigation", Journal of Computer Information Systems, Vol.47, No.4, (2007), pp. 28-44.

[11] Huang Z \& Palvia P, "Erp implementation issues in advanced and developing countries", Business process management journal, Vol.7, No.3, (2001), pp.276-284.

[12] Hitt LM, Wu DJ \& Zhou X, "Investment in enterprise resource planning: Business impact and productivity measures", Journal of management information systems, Vol.19, No.1, (2002), pp.71-98.

[13] Monk E \& Wagner B, "Concepts in enterprise resource planning", Cengage Learning, (2012).

[14] Qu WG, Pinsoneault A \& Oh W, "Influence of industry characteristics on information technology outsourcing", Journal of Management Information Systems, Vol.27, No.4, (2011), pp.99128. 
[15] Langenwalter GA, Enterprise resources planning and beyond: integrating your entire organization, CRC Press, (1999).

[16] Edmund Christopher S, "A Study on Buying Behaviour of Customers Towards Branded and Non-Branded Gold Jewellery with Reference to Kanyakumari District", International Journal of Management (IJM), Vol.5, No.10, (2014), pp.105-114.

[17] Edmund Christopher S, "Relaunching the Retailing in Small Towns: New Growth Frontiers Open Up in Rural India", International Journal of Marketing, Financial Services \& Management Research, Vol.3, No.7, (2014), pp.57-66.

[18] Edmund Christopher S, "Reengineering the Process of Performance Evaluation towards the Employee's Development - Need of the Time in IT Industry", Journal of Chemical and Pharmaceutical Sciences, (2016), pp.1823-1826.

[19] Edmund Christopher S, “A Whiff of IT Industry Work Stress and Accelerating the Productivity: with Special Reference to Indian IT Industry", Zenith International Journal of Business Economics and Management Research, (2014)

[20] Edmund Christopher S, "Drain the Women Entrepreneurial Effor to Manage Global Crisis is The Need of an Hour-A Focus Based on Indian Context GE", International Journal of Management Research (GE-IJMR), (2016), pp.87-97.

[21] Edmund Christopher S, "An analytical Study on Service Quality of Air India with Special Reference to Southern Region", International Journal of Applied Engineering Research, Research India Publications, Vol.10, No.45, (2015), pp.32021-32024.

[22] Edmund Christopher S, "Employee Training and Development Practices in Air India-A Descriptive Glance with Reference to Chennai", International Journal of Applied Engineering Research, Research India Publications, Vol.10, No.45, (2015), pp.3200532008.

[23] Edmund Christopher S, "Performance of Air India with Special Reference to Passenger Fluctuations-A Focus", Indian Stream Research Journal, Vol.4, No.10, (2014), pp.01-06.

[24] Dhanya JS \& Kinslin D, “A Study on Impact of Work Life Balance on Retention of Women Teachers in Management Colleges in Kerala”, International Journal of Applied Business and Economic Research, Vol.15, No.4, (2017).

[25] Dhanya JS \& Kinslin D, "A Study on Work Life Balance of Women Employeees at ULCCS Ltd., Kozhikode", International Journal of Applied Business and Economic Research, Vol.15, No.4, (2017).

[26] Dhanya JS \& Kinslin D, "Clair Model for Better Work Life Balance and Empowerment of Women Faculty in Professional Colleges of Kerala", International Journal of Applied Business and Economic Research, Vol.15, No.4, (2017).

[27] Kochukalam C \& Kinslin D, "A Study on the Factors for Intermediary Dependence Among Decorative Paint Customers Exploring the impact significance", International Journal of Applied Business and Economic Research, Vol.15, No.6, (2017).

[28] Kochukalam C \& Kinslin D, “A Study Among Decorative Paint Customers on Factors Influencing Preference of Decorative Paint Brands", International Journal of Applied Business and Economic Research, Vol.15, No.6, (2017).

[29] Kochukalam C \& Kinslin D, "Problems and Challenges of Decorative Paint Customers in Paint Preference: A Study Among Decorative Paint Customers of Kerala", International Journal of Applied Business and Economic Research, Vol.15, No.6, (2017).

[30] Kochukalam C \& Kinslin D, “A study Explaining Branding Brand Experience Among Decorative Paint customers", International Journal of Applied Business and Economic Research, Vol.15, No.6, (2017).

[31] Shaji Y, Kinslin D \& Janardhanan KA, "Employee Retention Practices for Leaders-A Study in Information Technology Organization", International Journal of Applied Engineering Research, Vol.10, (2015). 